\title{
Research observation: Nitrogen effects on Arizona cotton- top and Lehmann lovegrass seedlings
}

\author{
MARIA E. FERNANDEZ-GIMÉNEZ AND STEVEN E. SMITH
}

Authors are Assistant Professor and Associate Professor, School of Renewable Natural Resources, 325 Biosciences East, University of Arizona, Tucson, Ariz. 85721; 520-621-1105; gimenez@ag.arizona.edu

\section{Abstract}

We compared the responses of seedlings of introduced Lehmann lovegrass (Eragrostis Lehmanniana Nees) and a native perennial grass, Arizona cottontop (Digitaria californica (Benth.) Henr.) to 7 nitrogen and 2 water treatments to determine if Lehmann lovegrass displayed greater growth or nitrogen use efficiency than Arizona cottontop. After 8 weeks, the lovegrass seedlings had greater shoot $N$ concentrations $(2.07$ vs. $1.20 \%)$, and lower $C: \mathbb{N}$ ratios (27.7 vs. 49.6) than Arizona cottontop seedlings. Arizona cottontop seedlings produced more biomass per plant (1.09 vs. $0.31 \mathrm{~g}$ ), exhibited greater nitrogen use efficiency (63 vs. $39 \%$ ), and tolerated high $\mathbf{N}$ levels better. Arizona cottontop may be a superior $\mathbf{N}$ competitor under both $\mathbf{N}$-limited and high $\mathbf{N}$ conditions, while Lehmann lovegrass may outcompete Arizona cottontop at moderate $\mathbf{N}$ levels.

Key Words: invasive plant, nitrogen dynamics, nitrogen use efficiency, desert grassland, plant strategies

Invasive, non-native grasses affect the diversity of native vegetation communities and associated fauna (Bock et al. 1986), and may influence fire, nutrient and hydrologic cycles (D'Antonio and Vitousek 1992, Evans et al. 2001, Williams and Baruch 2000). Lehmann lovegrass (Eragrostis Lehmanniana Nees) was introduced to southern Arizona in 1932 and now occurs on at least 200,000 ha throughout southeastern Arizona (Cox et al. 1990). Arizona cottontop (Digitaria californica (Benth.) Henr.) is a native perennial bunchgrass considered to be a "climax dominant" in the semi-desert grassland where Lehmann lovegrass is now common (Cable 1979).

A number of mechanisms have been proposed to explain the invasive success of Lehmann lovegrass, including the large number of seeds produced, their persistence in the soil and delayed germination after late summer rains or prolonged drought (Abbott et al. 1995, Cox and Ruyle 1986); high temperature of optimal germination compared to native grasses (Cox et al. 1988, Martin

This study was funded in part by a University of Arizona Faculty Small Grant. Thanks to Mark Pater and Bruce Munda, USDA-NRCS, Tucson Plant Materials Center, for providing seed for this experiment; Simmyrong Cho and Alexander Conley for assistance in tending, harvesting and processing samples; Debra Fendenheim for greenhouse management and data entry; Thomas Thompson for advice on experimental treatments and design; David Williams, Mitch McClaran, and two anonymous reviewers for helpful comments on the manuscript; and Andres Cibils for translating the abstract.

Manuscript accepted 18 Apr. 03.

\section{Resumen}

Se compararon las respuestas de plántulas de una gramínea introducida (Eragrostis lehmanniana Nees) y una gramínea nativa perenne (Digitaria californica (Benth) Henr.) a 7 tratamientos de nitrógeno y 2 tratamientos de riego, para determinar si $\mathbf{E}$. lehmanniana exhibía mayor crecimiento o eficiencia en el uso del nitrógeno que D. californica. Después de 8 semanas, las plántulas de $\mathbf{E}$. lehmanniana exhibieron mayor concentración de $\mathbf{N}$ en biomasa aérea $(2.07$ vs. $1.20 \%)$, y una relación $\mathrm{C}: \mathrm{N}$ más baja (27.7 vs. 49.6) que las plántulas de $D$. californica. Las plántulas de $D$. californica produjeron más biomasa por planta (1.09 vs. $0.31 \mathrm{~g}$ ), exhibieron mayor eficiencia en el uso del nitrógeno (63 vs. $39 \%$ ), y toleraron mejor condiciones de alto nivel de N. D. californica podría ser un competidor superior por $\mathbf{N}$ tanto en condiciones de $\mathbf{N}$ limitante como en aquellas de alto nivel de $\mathbf{N}$, mientras que E. lehmanniana podría superar a $\mathbf{D}$. californica en la competencia por $\mathbf{N}$ bajo niveles moderados de este nutriente.

and Cox 1984); and relative unpalatability compared to natives (Cox et al. 1990). Lehmann lovegrass also can use soil water during the winter and early spring, when other warm-season plants are generally considered to be dormant, and is able to extract soil water at very low soil water potential (Frasier and Cox 1994).

Few data are available on nutrient uptake or nutrient use efficiency of Lehmann lovegrass. In a greenhouse experiment, total belowground nitrogen $(\mathrm{N})$ was significantly reduced in defoliated mature Arizona cottontop plants compared to undefoliated plants but was unchanged in Lehmann lovegrass plants (Cox et al. 1992). Other studies have shown that high fertility sites are vulnerable to invasion by non-native plants, including grasses (Stohlgren et al. 1998, Burke and Grime 1996, Wilson and Tilman 2002), although some research has not supported this hypothesis (Lowe et al. 2002). In contrast, native species may successfully exclude invaders under low nutrient conditions (Huenneke et al. 1990, McLendon and Redente 1991). Williams and Baruch (2000) suggest that some invasive African grasses may be superior competitors under very low nutrient conditions, and that other invaders have high nutrient requirements and respond dramatically to nutrient additions, but also use nutrients more efficiently than native grasses (traits that are usually negatively correlated in plants). If Williams and Baruch (2000) are correct, these invaders should be competitively superior to native grasses in both fertile and nutrient-poor environments.

We studied the $\mathrm{N}$ dynamics of Lehmann lovegrass and Arizona cottontop seedlings to elucidate possible mechanisms responsible for Lehmann lovegrass's invasion success. Our objective was to 
compare the responses of Lehmann lovegrass and Arizona cottontop seedlings to 7 levels of $\mathbf{N}$ under 2 watering regimes. In accordance with the predictions of Williams and Baruch (2000), and indications that Lehmann lovegrass has more efficient water use characteristics (Frasier and Cox 1994), we hypothesized that: 1) Lehmann lovegrass would show a greater growth response to $\mathrm{N}$ additions than Arizona cottontop, measured as absolute biomass produced per plant and as biomass produced relative to the maximum production for a given species in this experiment; 2) Lehmann lovegrass would display greater nitrogen use efficiency (NUE) than Arizona cottontop; and, 3) Lehmann lovegrass seedlings would outperform Arizona cottontop seedlings at low water levels, as measured by biomass per plant, relative biomass production, NUE, and \% $\mathrm{N}$ tissue content (an indicator of $\mathrm{N}$ uptake).

\section{Materials and Methods}

Arizona cottontop and Lehmann lovegrass seedlings were grown in a greenhouse for 8 weeks with $7 \mathrm{~N}$ treatments and 2 water treatments in a split-split plot design with 4 replications in a randomized complete block design, in which water treatments = main plot, $\mathrm{N}$ levels = sub plot, and species = sub-sub plot. Each sub-sub plot included 7 plants, which were treated as individuals. Mean temperature in the greenhouse was $29^{\circ} \mathrm{C}$ (mean low $22^{\circ} \mathrm{C}$; mean high $36^{\circ} \mathrm{C}$ ) to simulate typical growing conditions for $\mathrm{C}_{4}$ grasses.

Arizona cottontop seeds (caryopses with glumes and lemmas) were collected in 1994 from a population on the Santa Rita $\left(31^{\circ} 50^{\prime} 16^{\prime \prime} \mathrm{N}, 110^{\circ} 50^{\prime} 34^{\prime} \mathrm{W}\right)$. Lehmann lovegrass A-68 seeds were provided by the USDA-NRCS Tucson Plant Materials Center ( $\left.32^{\circ} 16^{\prime} 49^{\prime \prime} \mathrm{N}, 111^{\circ} 0^{\prime} 39^{\prime \prime} \mathrm{W}\right)$. The plants were grown in a mixture of 1 part acid-washed sand and 2 parts vermiculite (by volume). The mixture was wetted slightly with tap water and then was used to fill $20 \times 5-\mathrm{cm}\left(30 \mathrm{~cm}^{3}\right)$ tapered cones (Conetainers). Lehmann lovegrass requires light to germinate while Arizona cottontop does not. Acid-washed sand (5 $\mathrm{ml}$ ) was placed in the cones assigned to Lehmann lovegrass and seeds were placed on top of the sand. Arizona cottontop seeds were placed directly on the sandvermiculite mixture or soil (see below) and covered with $5 \mathrm{ml}$ of acid-washed sand. Approximately 5 seeds were sown in each cone, and thinned to 1 plant per cone after germination. All cones were kept moist to facilitate rapid germination. Six days after sowing, the 2 water treatments were applied. Plants in the high water treatment were watered daily to beyond field capacity and those in the low water treatment were watered likewise but on alternate days.

With imposition of water treatments, 7 $\mathrm{N}$ treatments were applied to the cones once a week for the duration of the experiment ( 8 weeks), using 1 x Hoagland's solution (Hoagland and Arnon 1950) but with varying levels of $\mathrm{N}$. The $\mathrm{N}$ treatments ( $\mathrm{mg} \mathrm{N} / \mathrm{ml}$ solution or \% $\mathrm{N}$ in solution) were: $0,0.013,0.028,0.067,0.133,0.280$, and 0.700 . Treatment levels were selected to represent our best estimate of $0,5,10$, $25,50,100$, and $250 \%$ of weekly $\mathrm{N}$ uptake by Arizona cottontop. We calculated this estimate by multiplying the plant biomass produced by 8 -week old Arizona cottontop plants grown in the greenhouse under conditions similar to those of this experiment (S.E. Smith, unpublished data) by published estimates of Arizona cottontop root and shoot N (Cox et al. 1992) and multiplying the result by 4 to reflect an assumed $25 \% \mathrm{~N}$ use efficiency.

On areas of the Santa Rita where Arizona cottontop was once common, total soil $\mathrm{N}$ varies from $0.027 \%$ in open grasslands to $0.083 \%$ under the canopy of mesquite trees (Barth and Klemmedson 1978, Tiedemann and Klemmedson 1973). Along historical grazing pressure gradients radiating out from water points (piospheres) on the Santa Rita, total soil N varied from $0.042 \% 100 \mathrm{~m}$ from water to $0.083 \%$ immediately adjacent to water points. Mean total soil $\mathrm{N}$ over the entire piosphere $(1000 \mathrm{~m})$ was $0.050 \%$ (M.E. Fernandez-Gimenez and S.E. Smith, unpublished data).

To assess the validity of our treatment levels relative to $\mathrm{N}$ levels in native soils, we also planted Arizona cottontop and Lehmann lovegrass in cones filled with native soil from the Santa Rita (CombateDiaspar Series; thermic Ustic Torrifluvent) and applied the same water treatments. In all treatments, tap water was applied on days other than when $\mathrm{N}$ applications were required.

Seeds were sown on 2 Aug. 2000 and the final $\mathrm{N}$ application occurred on 22 Sept. 2000. Aboveground biomass was harvested by clipping shoots at the soil surface on 27 Sept. 2000. Roots were harvested on 4 and 5 Oct. 2000, and washed to remove excess sand and vermiculite before drying. Roots were harvested from 3 plants (nos. 2, 4, and 6) per sub-sub plot.
Shoots and roots were stored in paper bags and air dried for 4-8 weeks. After weighing, the shoots from each treatment by replicate combination were combined and ground in a Wiley mill with a $1 \mathrm{~mm}$ screen. The same was done for roots. These bulked root and shoot samples from Replicates II and IV were analyzed by combustion for total $\mathrm{C}$ and total $\mathrm{N}$ using a Leco CNS-2000 autoanalyzer (IAS Laboratories, Phoenix, Ariz.). Twentyfour out of 152 samples were not analyzed due to insufficient tissue mass.

\section{Calculations and Statistical Analyses}

To account for the inherent differences in seedling development, largely due to differences in caryopsis mass between Arizona cottontop and Lehmann lovegrass, we compared their response to $\mathrm{N}$ additions by examining the response of each species as a percentage of mean maximum biomass in the treatment combination with the highest biomass for that species in this experiment. Nitrogen use efficiency (NUE) was calculated as the ratio of $\mathrm{g}$ biomass produced per $\mathrm{g} \mathrm{N}$ within that biomass (plant total mass / [(plant $\% \mathrm{~N} / 100)($ plant total mass)]).

Data were analyzed using PROC GLM of SAS (SAS Institute 1989) using a complete mixed-effects model for a split-split plot design with replications considered random effects. Means were compared using Duncan's Multiple Range test. Before analysis, normality was evaluated using the method of Shapiro and Wilk (Shapiro and Wilk 1965) and homogeneity of variances tested using the Fmax test (Sokal and Rohlf 1981). In neither case were significant deviations from the assumptions underlying the analysis of variance observed. Statistical significance was determined at $\mathrm{P} \leq 0.05$ throughout.

\section{Results}

\section{Shoot and Root Biomass}

Arizona cottontop and Lehmann lovegrass seedlings differed in their response to varying $\mathrm{N}$ levels, and these responses were dependent on water level. Shoot biomass of both species increased with increasing $\mathrm{N}$ treatment levels from $0.013 \% \mathrm{~N}$ to $0.280 \% \mathrm{~N}$ (Fig. 1). Lehmann lovegrass shoot biomass declined significantly at the highest $\mathrm{N}$ level $(0.700 \% \mathrm{~N})$, while Arizona cottontop's did not. Arizona cot- 


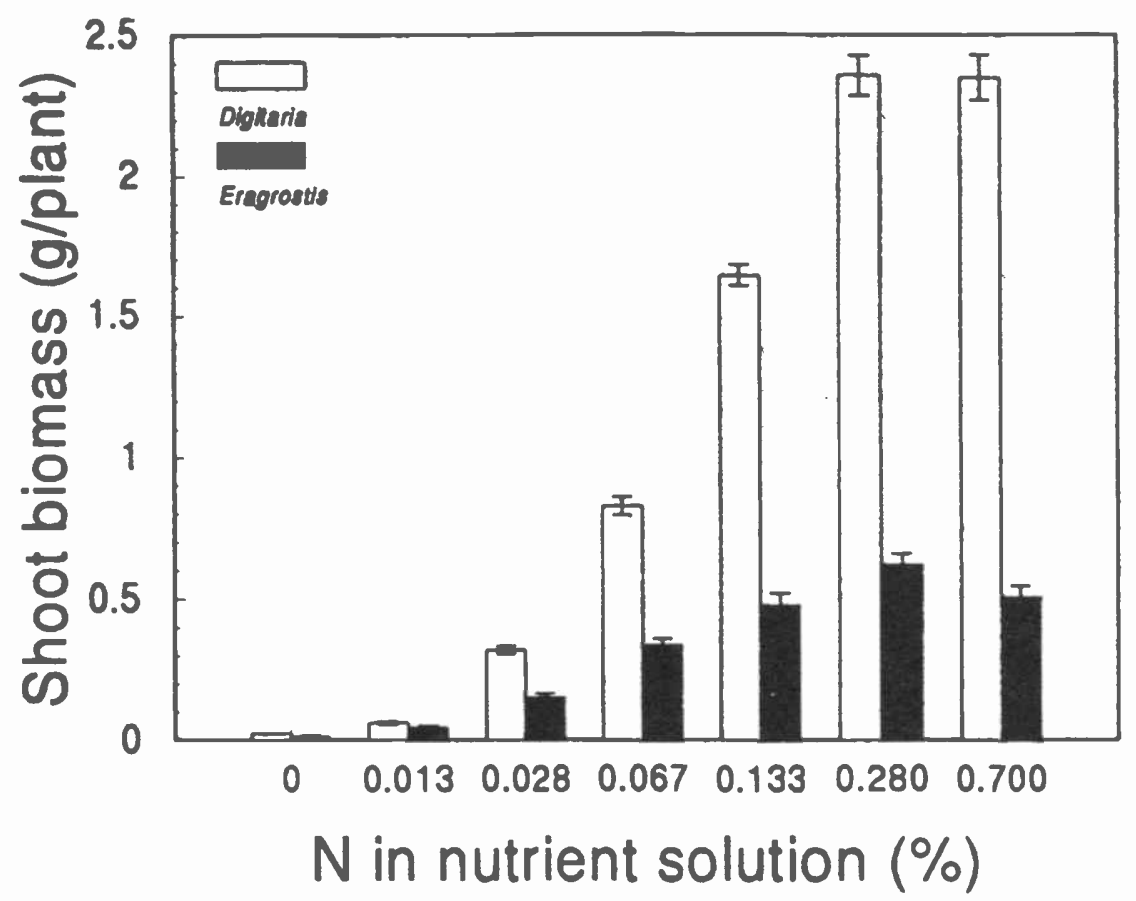

Fig. 1. Shoot biomass response of an exotic, invasive grass, Lehmann lovegrass (Eragrostis), and a native grass, Arizona cottontop (Digitaria), to a gradient of nitrogen availability. Both species were grown from seed in a greenhouse for 8 weeks. Error bars are the standard error of the mean.

tontop shoot biomass was significantly greater than that of Lehmann lovegrass overall. However, when Arizona cottontop and Lehmann lovegrass responses were compared on the basis of percent of maximum biomass yield in this experiment, Lehmann lovegrass production was consistently greater than Arizona cottontop's, except at the highest $\mathrm{N}$ level (Fig. 2).

Arizona cottontop produced greater biomass with the high water treatment, as expected. However, Lehmann lovegrass biomass production was higher with the low water treatment. When the $\mathrm{N} \mathrm{x}$ water $x$ species interaction was examined, it appeared that Lehmann lovegrass shoot growth was retarded by the combination of high $\mathrm{N}$ and saturated water conditions.

Mean shoot biomass over both species was greater in native soil $(0.04 \mathrm{~g})$ than in the $0 \mathrm{~N}$ treatment $(0.02 \mathrm{~g})$, and lower than the $0.013 \% \mathrm{~N}$ treatment $(0.06 \mathrm{~g})$. The same pattern held for Arizona cottontop and Lehmann lovegrass individually.

Root biomass followed a similar pattern to shoot biomass, increasing with increasing $\mathrm{N}$ levels. Arizona cottontop root biomass peaked at $0.700 \% \mathrm{~N}$ while Lehmann lovegrass biomass peaked at $0.280 \%$ and declined sharply at $0.700 \%$. In contrast to shoot biomass, Arizona cottontop demonstrated a greater response to $\mathrm{N}$ additions both in terms of absolute biomass producing more root biomass at $\mathrm{N}$ levels over $0.028 \%$ under the low water treatment, and Arizona cottontop producing more at or above the $0.280 \% \mathrm{~N}$ treatment level under the high-water treatment.

\section{Shoot and Root $N$ Concentrations and $C: N$ Ratio}

Lehmann lovegrass shoot $\mathrm{N}$ increased more with increasing $\mathrm{N}$ levels than Arizona cottontop shoot N. Lehmann lovegrass shoot $\mathrm{N}$ also differed more between water treatments under low $\mathrm{N}$ than high $\mathrm{N}$, leading to significant interaction effects. For both species, shoot $\mathrm{N}$ was greatest at the highest $\mathrm{N}$ levels, and differed significantly among most levels (Fig. 3). Lehmann lovegrass mean shoot $\mathrm{N}$ $(2.08 \%)$ was significantly greater than that of Arizona cottontop (1.21\%), and shoot N for both species was greater under the high water treatment. Root $\mathrm{N}$ was also greatest with the highest $\mathrm{N}$ level, but did not differ between species or water treatments.

The C: $\mathrm{N}$ ratio declined significantly with increasing $\mathrm{N}$ in both species, but Lehmann lovegrass C: $\mathrm{N}$ declined more, while the $\mathrm{C}: \mathrm{N}$ ratio of Arizona cottontop remained elevated until the $0.280 \% \mathrm{~N}$ treatment, at which point it dropped significantly (Fig. 4). Lehmann lovegrass mean C:N (27.7) was significantly lower than Arizona cottontop's (49.6). (g/plant) and when response was calculated as the fraction of maximum biomass. A significant $\mathrm{N} x$ water $\mathrm{x}$ species interaction was observed, with Lehmann lovegrass

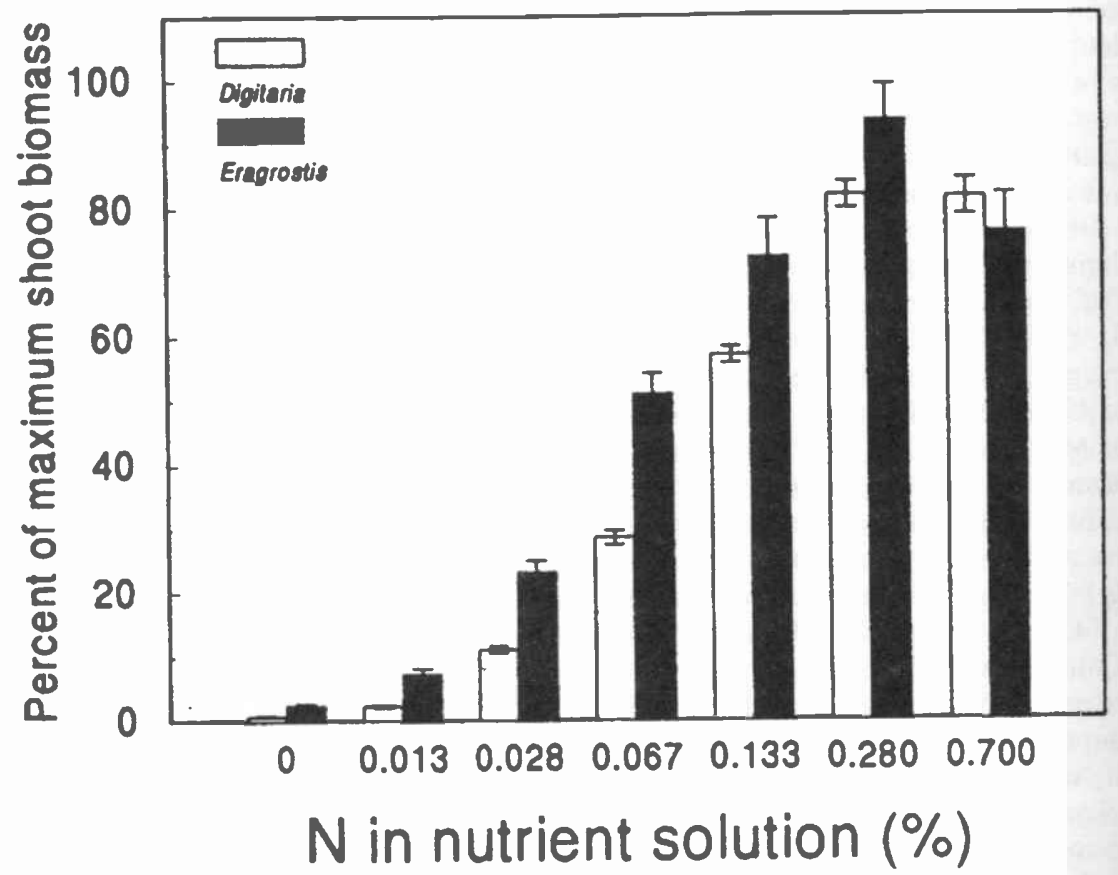

Fig. 2. Biomass response of an exotic, invasive grass, Lehmann lovegrass (Eragrostis), and a native grass, Arizona cottontop (Digitaria), to a gradient of nitrogen availability, expressed of as a percentage of maximum shoot biomass for each species in this experiment. Both species were grown from seed in a greenhouse for $\mathbf{8}$ weeks. Error bars are the standard error of the mean. 


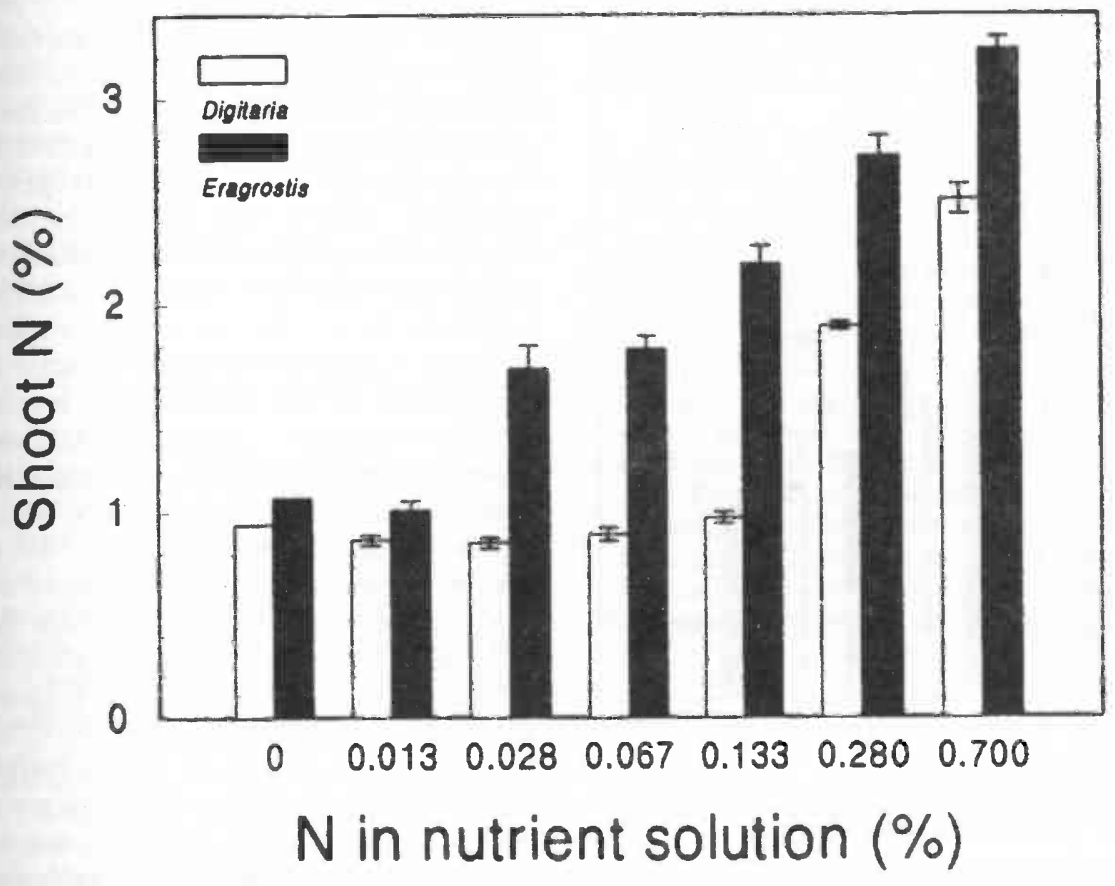

Fig. 3. Shoot $\mathrm{N}$ concentration $(\%)$ of an exotic, invasive grass, Lehmann lovegrass (Eragrostis), and a native grass, Arizona cottontop (Digitaria), in response to a gradient of nitrogen availability. Both species were grown from seed in a greenhouse for 8 weeks. Error bars are the standard error of the mean.

\section{Nitrogen Use Efficiency}

Arizona cottontop 's mean NUE $(63.1 \%)$ was significantly greater than that of Lehmann lovegrass (39.3\%), but only at $\mathrm{N}$ levels below $0.280 \%$. The NUE of both species was lowest at the highest $\mathrm{N}$ levels $(0.280 \%$ and $0.700 \%)$ (Fig. 5). Water level did not affect the NUE of either species.

\section{Discussion}

Our objective in this experiment was to compare the responses of Lehmann lovegrass and Arizona cottontop seedlings to varying $\mathrm{N}$ levels under contrasting water regimes to determine whether differing growth responses to $\mathrm{N}$ or resource use efficiencies might be associated with the invasive success of Lehmann lovegrass in Arizona's desert grasslands. We posited that if superior resource use efficiency or more dramatic seedling growth response to $\mathrm{N}$ contribute to Lehmann lovegrass success, we would observe a steeper growth curve in response to increasing $\mathrm{N}$ levels in Lehmann lovegrass seedlings than Arizona cottontop seedlings (hypothesis 1), and/or greater NUE in Lehmann lovegrass (hypothesis 2). We also expected that Lehmann lovegrass seedlings would perform better under water-limited conditions than Arizona cottontop seedlings (hypothesis 3). accounted for. However, Lehmann lovegrass seedlings also experienced apparent $\mathrm{N}$ toxicity at the highest $\mathrm{N}$ treatment level, especially under high soil moisture conditions. Arizona cottontop seedlings produced more biomass per plant than Lehmann lovegrass seedlings. Lehmann lovegrass seedlings appear to be more effective in acquiring $\mathrm{N}$ than Arizona cottontop, as indicated by greater shoot $\mathrm{N}$ concentrations and lower C:N ratios, regardless of water level. However, Arizona cottontop exhibited greater NUE, and tolerated high $\mathrm{N}$ levels better than Lehmann lovegrass seedlings. Thus, hypothesis 1 is partially supported (when relative shoot production is considered), and hypothesis 2 is clearly rejected. Hypothesis 3 is also rejected since there were no situations in which Lehmann lovegrass seedlings outperformed Arizona cottontop seedlings under low water conditions but not high water conditions, although Lehmann lovegrass showed higher relative shoot biomass, greater $\mathrm{N}$ tissue concentration, and lower $\mathrm{C}: \mathrm{N}$ ratios, regardless of water level, while Arizona cottontop showed superior NUE and absolute biomass at both water levels. A potential limitation of our study is that the low-water treatment (watering on alternate days vs. daily) may not have imposed sufficient water stress to cause a detectable difference in some plant response variables.

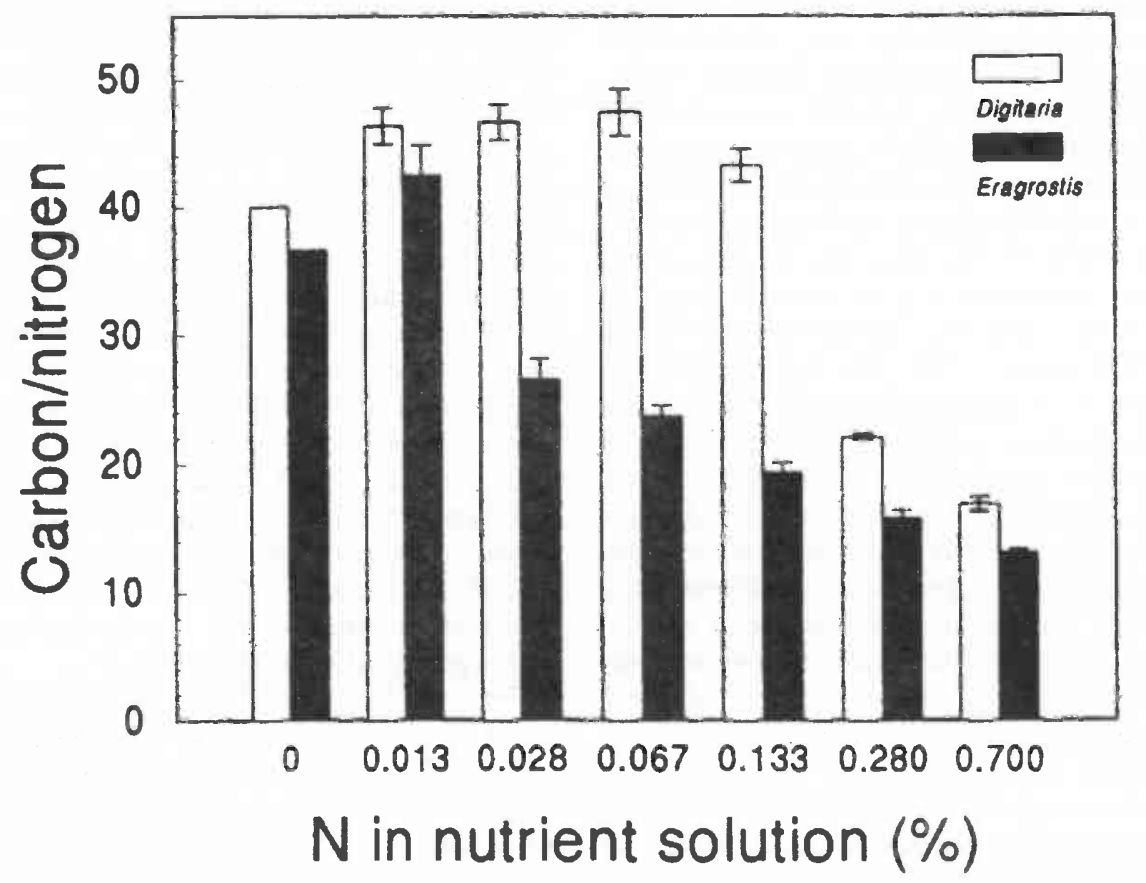

Fig. 4. The C:N ratio of an exotic, invasive grass, Lehmann lovegrass (Eragrostis), and a native grass, Arizona cottontop (Digitaria), in response to a gradient of nitrogen availability. Both species were grown from seed in a greenhouse for 8 weeks. Error bars are the standard error of the mean. 


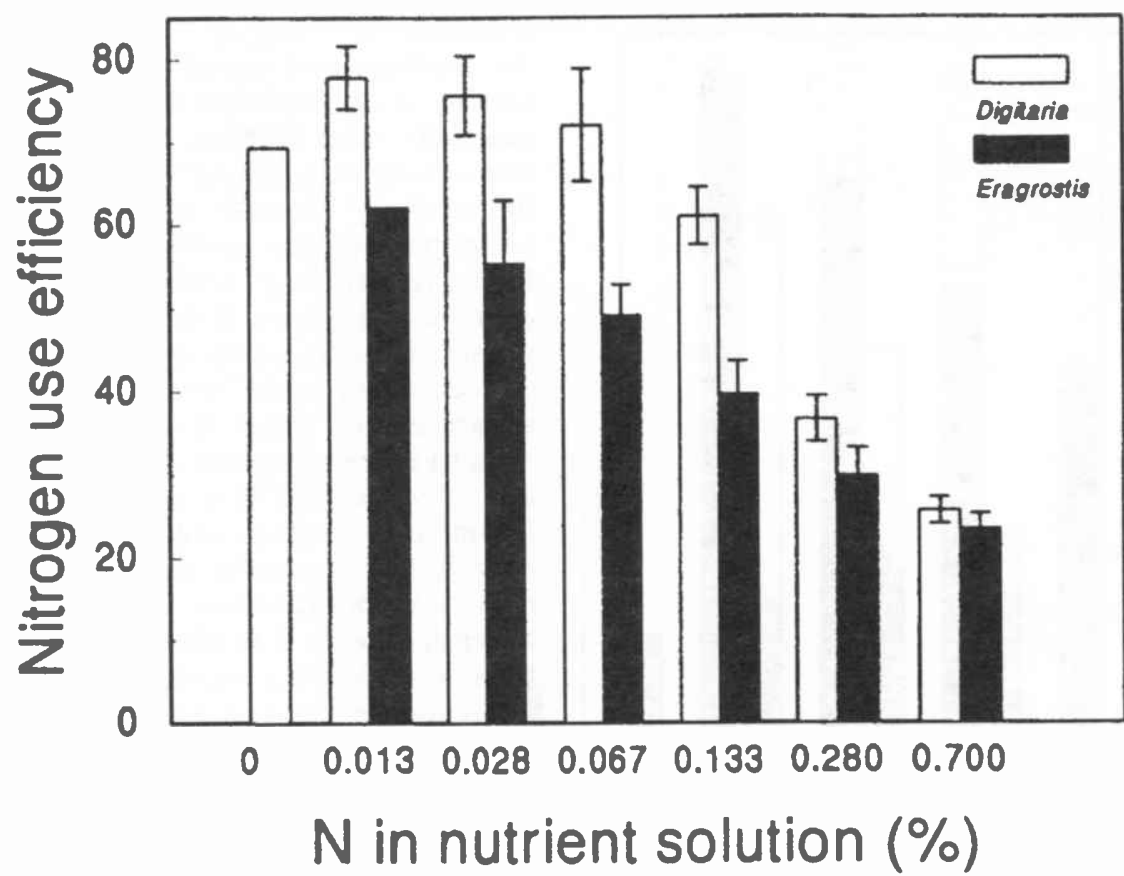

Fig. 5. Nitrogen use efficiency of an exotic, invasive grass, Lehmann lovegrass (Eragrostis), and a native grass, Arizona cottontop (Digitaria), in response to a gradient of nitrogen availability. Both species were grown from seed in a greenhouse for 8 weeks. Error bars are the standard error of the mean.

These results do not point clearly to a nitrogen-related explanation for the invasive success of Lehmann lovegrass in desert grasslands where Arizona cottontop is historically a climax dominant. In addition, the life history traits and nitrogen gradient responses of Lehmann lovegrass and Arizona cottontop only partially conform with existing plant strategy theory, and present some apparent contradictions. The greater nutrient concentrations and growth response, and lower $\mathrm{C}: \mathrm{N}$ ratio of Lehmann lovegrass seedlings are consistent with the characteristics of a "competitive" species or a plant adapted to a relatively productive environment (Chapin 1980, Grime 1979). The prolific seed production of Lehmann lovegrass and its relatively short lifespan are typical traits of ruderal species (Grime 1979). However, the apparent toxicity response to elevated $\mathrm{N}$ levels would be expected of a stress-tolerant plant adapted to low nutrient sites, not a fast-growing competitor or ruderal (Grime 1979). Arizona cottontop exhibits some classic traits of "stress tolerant" strategists, such as greater NUE and lower tissue $\mathrm{N}$, as well as a lower growth response to $\mathrm{N}$ additions when adjusted for differences in inherent biomass production potential between species (Chapin 1980, Grime 1979). However, Arizona cottontop produced more total biomass with increasing $\mathrm{N}$ than Lehmann lovegrass, and main- tained maximum production at the highest $\mathrm{N}$ level, with no indication of a toxicity response. Arizona cottontop 's relatively large caryopses, with a mass approximately 11 times greater than Lehmann lovegrass (Smith et al. 2000), and small number of seeds per plant are traits associated with a high growth rate and competitive strategy (Berendse and Elberse 1990). Arizona cottontop 's apparent ability to reallocate resources rapidly, as indicated by the dramatic decline in belowground $\mathrm{N}$ after defoliation (Cox et al. 1992), suggests greater plasticity in resource allocation than Lehmann lovegrass, another trait more common in competitors and plants from nutrient rich environments (Chapin 1980, Grime 1979). Finally, while Arizona cottontop seedlings produced more biomass per plant than Lehmann lovegrass in this experiment, in an earlier field study conducted on the Santa Rita, mature plants of Lehmann lovegrass produced 4 times more shoot biomass per unit area than native grasses (Cox et al. 1990).

Thus, while our results initially suggest that Lehmann lovegrass and Arizona cottontop offer an example of the seedlingstage trade-offs between ruderal and stress-tolerant strategies, on consideration, each species possesses a suite of traits associated with 2 or more strategies. According to Grime's classification, Lehmann lovegrass may be a ruderal-com- petitive-stress tolerant strategist, and Arizona cottontop a stress-tolerant competitor. Unfortunately, these classifications do not help determine which specific traits explain the invasive success of Lehmann lovegrass. Since Lehmann lovegrass seedlings used $\mathrm{N}$ less efficiently than Arizona cottontop at low and moderate $\mathrm{N}$ levels and exhibited a toxicity response at elevated $\mathrm{N}$ levels, we would expect Arizona cottontop to be the superior $\mathrm{N}$ competitor at low and high $\mathrm{N}$ levels. Lehmann lovegrass's greater $\mathbf{N}$ uptake and growth response to $\mathrm{N}$ may enhance its competitive fitness at moderate $\mathrm{N}$ levels, where Arizona cottontop's greater NUE is less of an advantage. Our findings thus neither support nor definitively refute the hypothesis that high fertility sites are more vulnerable to invasion by exotic, invasive plant species (Burke and Grime 1996, Grime 1979). Lowe et al. (2002) studied the response to $\mathrm{N}$ additions of 4 exotic and 2 native species and also found no consistent pattern to support this hypothesis. Direct competition experiments and field studies are needed to determine whether Lehmann lovegrass outcompetes Arizona cottontop under low, moderate or elevated $\mathrm{N}$ regimes.

Our findings have potential implications for interpretation of some vegetation patterns observed in prior fieldwork. Since Arizona cottontop seedlings performed better than Lehmann lovegrass seedlings under very high $\mathrm{N}$ levels, $\mathrm{N}$ additions may enhance Arizona cottontop 's competitive success relative to Lehmann lovegrass. If true, this outcome would contradict previous findings that native species are more successful under low nutrient conditions (Huenneke et al. 1990, McLendon and Redente 1991).

The higher $\mathrm{N}$ concentrations and lower $C: N$ ratio found in Lehmann lovegrass seedlings contradicts earlier studies in which this species was shown to have lower $\mathrm{N}$ concentrations in belowground tissues than Arizona cottontop, as well as lower crude protein content than native grasses (Cox et al. 1992). This finding also runs counter to the generalization that introduced African grasses often exhibit greater $C: N$ ratios than native grasses, although evidence for this claim is more equivocal in arid environments than in the tropics (Williams and Baruch 2000). If the $C: N$ ratio of mature Lehmann lovegrass plants is lower than that of Arizona cottontop and other native grasses under field conditions, we speculate that the expansion of Lehmann lovegrass over broad areas of southern Arizona could potential- 
ly alter ecosystem properties by increasing litter quality and lowering the soil $\mathrm{C}: \mathrm{N}$ ratio. Such changes, if they occur, in turn may affect competitive interactions among native and invasive species in Arizona's desert grasslands by altering soil nitrogen availability. These potential impacts remain speculative until further work is done to verify our results in a field setting.

\section{References}

Abbott, L. B., B. A. Roundy, and S. H. Biedenbender. 1995. Seed fate of warm-season perennial grasses, p. 37-43. In: Intermountain Research Station, USDA For. Serv. General Tech. Rep. INT-GTR-317.

Barth, R. C. and J. O. Klemmedson. 1978. Shrub-induced spatial patterns of dry matter, nitrogen, and organic carbon. Soil Sci. Soc. of Amer. J. 42: 804-809.

Berendse, F. and W. T. Elberse. 1990. Competition and nutrient availability in heathland and grassland ecosystems, p.93-116. In: J. B. Grace and D. Tilman (eds.) Perspectives on plant competition. Academic Press, Inc., San Diego, Calif.

Bock, C. E., J. H. Bock, K. L. Jepson, and J. C. Ortega. 1986. Ecological effects of planting African Lehmann lovegrasses in Arizona. Nat. Geogr. Res. 2: 456-463.

Burke, M. J. W. and J. P. Grime. 1996. An experimental study of plant community invasibility. Ecology 77:776-790.

Cable, D. R. 1979. Ecology of Arizona cottontop. Rocky Mountain Forest and Range Experiment Station, Fort Collins, Colo. Res. Paper RM-209.

Chapin, F. S. 1980. The mineral nutrition of plants. Annu. Rev. of Ecol. and Syst. 11: 233-260.
Cox, J. R. and G. B. Ruyle. 1986. Influence of climatic and edaphic factors on the distribution of Eragrostis Lehmanniana Nees in Arizona, USA. J. Grassl. Soc. South Afr. 3: 25-29.

Cox, J. R., G. B. Ruyle, and B. A. Roundy. 1990. Lehmann lovegrass in southeastern Arizona: biomass production and disappearance. J. Range Manage. 43:367-372.

Cox, J. R., M. Giner-Mendoza, A. K. Dobrenz, and M. Smith. 1992. Defoliation effects on resource allocation in Arizona cottontop (Digitaria californica) and Lehmann lovegrass (Eragrostis lehmanniana). J. Grassl. Soc. South Afr. 9:53-59.

Cox, J. R., M. H. Martin-R, F. A. Ibarra-F, J. H. Fourie, N. F. G. Rethman, and D. G. Wilcox. 1988. The influence of climate and soils on the distribution of four African grasses. J. Range Manage. 41:127-139.

D'Antonio, C. M. and P. M. Vitousek. 1992. Biological invasions by exotic grasses, the grass/fire cycle, and global change. Annu. Rev. Ecol. Syst. 23:63-87.

Evans, R. D., R. Rimer, L. Sperry, and J. Belnap. 2001. Exotic plant invasion alters nitrogen dynamics in an arid grassland. Ecol. Appl. 11: 1301-1310.

Frasier, G. W. and J. R. Cox. 1994. Water balance in pure stand of Lehmann lovegrass. J. Range Manage. 47:373-378.

Grime, J. P. 1979. Plant strategies and vegetation processes. John Wiley \& Sons., New York, N.Y.

Hoagland, D. R. and D. I. Arnon. 1950. The water-culture method for growing plants without soil. Calif. Agr. Ext. Sta. Circ. 347.

Huenneke, L. F., S. P. Hamburg, R. Koide, H. A. Mooney, and P. M. Vitousek. 1990. Effects of soil resources on plant invasion and community structure in Californian serpentine grassland. Ecol. 71:478-491.

Lowe, P. N., W. K. Lauenroth, and I. C. Burke. 2002. Effects of nitrogen availability on the growth of native grasses and exotic weeds. J. Range Manage. 55:94-98.
Martin, M. H. and J. R. Cox. 1984. Germination profiles of introduced Lehmann lovegrasses at six constant temperatures. J. Range Manage. 37:507-509.

McLendon, T. and E. F. Redente. 1991. Nitrogen and phosphorus effects on secondary succession dynamics on a semi-arid sagebrush site. Ecol. 72:2016-2024.

SAS Institute, I. 1989. SAS/STAT $®$ User's Guide, Version 6. Vol. 2, $4^{\text {th }}$ ed. SAS Institute, Cary, N.C.

Shapiro, S. S. and M. B. Wilk. 1965. An analysis of variance test for normality (complete samples). Biometrika 52:591-611.

Smith, S. E., E. Riley, J. L. Tiss, and D. M. Fendenheim. 2000. Geographical variation in predictive seedling emergence in a perennial desert grass. J. Ecol. 88: 139-149.

Sokal, R. R. and F. J. Rohlf. 1981. Biometry, $2^{\text {nd }}$ ed. W.H. Freeman, New York, NY.

Stohlgren, T. J., L. D. Schell, and B. Vanden Heuvel. 1998. How grazing and soil quality affect native and exotic plant diversity in Rocky Mountain grasslands. Ecol. Appl. 9: 45-64.

Tiedemann, A. R. and J. O. Klemmedson. 1973. Nutrient availability in desert grassland soils under mesquite (Propsopis juliflora) trees and adjacent open areas. Soil Sci. Soc. Amer. J. 37:107-111.

Williams, D. G. and Z. Baruch. 2000. African grass invasion in the Americas: ecosystem consequences and the role of ecophysiology. Biol. Invasions 2:123-140.

Wilson, S. D. and D. Tilman. 2002. Quadratic variations in old-field species richness along gradients of disturbance and nitrogen. Ecol. 83:492-504. 